\title{
Lettuce Cultivars for Insect Resistance in Southern Florida ${ }^{1}$
}

\author{
German Sandoya, Huangjun Lu, and Alan L. Wright ${ }^{2}$
}

\section{Introduction}

Lettuce is the most popular ingredient in salads and salad mixes consumed in the United States; in Florida, the crop is mostly planted in 10,000 acres in the Everglades Agricultural Area (EAA). Lettuce production practices in the EAA are unique because the growing season begins in October and harvest finishes in April. Florida's subtropical climate facilitates lettuce production from fall through spring, but the warm and moist conditions are also favorable for insect proliferation and damage. Insect pests cause direct (feeding) and indirect (contamination) damages to the lettuce crop. There are nine types of insects that can be serious pests of lettuce including aphids, caterpillars, darkling beetles, field crickets, leafhoppers, leafminers, springtails, thrips, and whiteflies. This publication is intended for county extension faculty and other leafy vegetables stakeholders who need to understand the threat that insects represent in the lettuce production in South Florida. Additionally, this article encourages leafy vegetable stakeholders to use cultivars and breeding lines that are resistant to a few of the most important lettuce insect pests in south Florida.

\section{Key Pests}

Banded cucumber beetle (BCB) (Diabrotica balteata)

(Figure 1A), serpentine leafminer (SL) (Liriomyza trifolii)

(Figure 1B), and aphids (Homoptera: Aphididae) (Figures
1C, 1D) are among the major insect pests that cause significant economic damage to lettuce in southern Florida.

$\mathrm{BCB}$ is a polyphagous (attacking many plant species) insect with a host spectrum of more than 50 plant species in 23 families (Saba 1970). BCB adults feeding on lettuce foliage leads to decreased photosynthetic area, increased vulnerability to diseases, and reduced market grade (Nuessly and Nagata 1993).

SL is a polyphagous insect and attacks lettuce and other vegetable crops (Drees and Jackman 1999). Plant leaves are damaged as SL larvae tunnel through the inner leaf tissue, producing so-called whitish "mines" that reduce the photosynthetic area. Lettuce becomes unmarketable if infestation is severe (Nuessly and Nagata 1994).

Several aphid species affect lettuce, including green peach aphid (Myzus percicae), potato aphid (Macrosiphum euphorbiae), the species Uroleucon pseudambrosiae, and lettuce aphid (Nasonovia ribisnigri). The lettuce aphid is a problem worldwide and has become problematic in the western United States and Canada (Liu and McCreight 2006; McCreight 2008). However, the first three species of aphids listed above are most economically damaging in Florida (Nuessly and Webb 2010). Although heavy aphid pressure can stunt plants, the major problem aphids cause is head contamination, which makes lettuce unmarketable.

1. This document is HS1196, one of a series of the Horticultural Sciences Department, UF/IFAS Extension. Original publication date February 2012. Revised June 2021. Visit the EDIS website at https://edis.ifas.ufl.edu for the currently supported version of this publication.

2. German Sandoya, assistant professor; Huangjun Lu, former assistant professor, Horticultural Sciences Department, UF/IFAS Everglades Research and Education Center, Belle Glade, FL; and Alan L. Wright, professor, Department of Soil and Water Sciences, UF/IFAS Indian River REC, Fort Pierce, FL; UF/ IFAS Extension, Gainesville, FL 32611.

The Institute of Food and Agricultural Sciences (IFAS) is an Equal Opportunity Institution authorized to provide research, educational information and other services

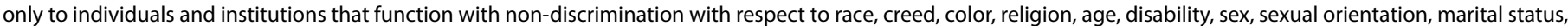

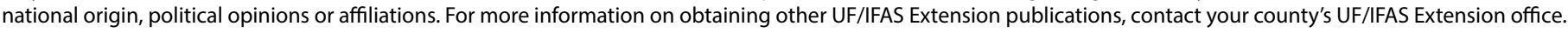
U.S. Department of Agriculture, UF/IFAS Extension Service, University of Florida, IFAS, Florida A \& M University Cooperative Extension Program, and Boards of County Commissioners Cooperating. Nick T. Place, dean for UF/IFAS Extension. 


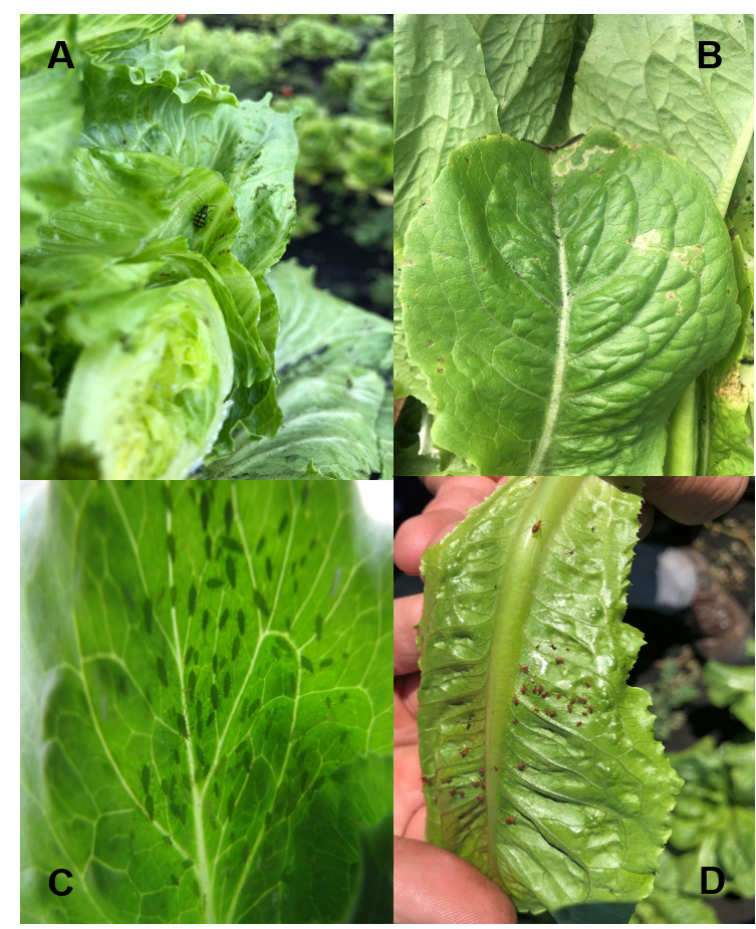

Figure 1. (A) Banded cucumber beetle - Diabrotica balteata, (B) serpentine leafminer Liriomyza trifolii, and (C, D) aphids (Homoptera: Aphididae)

Credits: UF/IFAS Lettuce Breeding Program

\section{Management by Host Plant Resistance}

$\mathrm{BCB}, \mathrm{SL}$, and aphid control in lettuce production is historically dependent on pesticide application. A detailed recommendation in pesticide labels approved for use in Florida are listed in the Vegetable Production Handbook of Florida, Chapter 9. Leafy Vegetable Production. However, there are disadvantages associated with pesticide use for insect control, including increased production costs, adverse environmental and ecological effects, and development of pesticide resistance in insects. One alternative for effective insect control is the use of host plant resistance, which is an environmentally friendly method that is compatible with other approaches used in integrated pest management (IPM) (Smith 1989).

Host plant resistanceto BCB and SL has been identified in lettuce. Nuessly and Nagata (1994) reported that 'Valmaine', a romaine lettuce cultivar, had a high level of resistance to SL. This cultivar was later found to be resistant to BCB (Huang et al. 2002; Sethi et al. 2008) and two lepidopterans, Trichoplusia ni and Spodoptera exigua (Sethi et al. 2006). 'Valmaine' is an obsoleteromaine cultivar that was used in lettuce production in the 1970s and then used as a parent for crosses to develop romaine cultivars in the University of Florida lettuce breeding program (Guzman 1986; Guzman and Zitter 1983). The cultivars 'Short
Guzmaine,' 'Tall Guzmaine, 'Floricos 83', and 'Floriglade' released in the 1980s (Guzman 1986; Guzman and Zitter 1983) contain 'Valmaine' in their pedigrees but have little SL resistance ('Short Guzmaine') or no resistance to either $\mathrm{SL}$ or $\mathrm{BCB}$, indicating that the high level of resistance in 'Valmaine' was not incorporated into these cultivars.

\section{Demonstration}

Three romaine cultivars ('Okeechobee,' 'Manatee,' 'Terrapin'), and one breeding line ('70096') and two iceberg cultivars ('Gator,' 'Raleigh'), and one breeding line ('8074') were evaluated in December 2010 and February 2011 for responses to $\mathrm{BCB}, \mathrm{SL}$, and aphid infestations in field experiments. 'Okeechobee, 'Manatee', and 'Gator' are cultivars currently used by Florida growers in lettuce production. 'Terrapin' and 'Raleigh' are cultivars developed by the UF/ IFAS lettuce breeding program but are no longer planted. Breeding lines 70096 and 8074 are elite lines in the UF/IFAS lettuce breeding program.

Breeding line '70096' had the least leaf foliar damage (3.7\%) by BCB (Table 1). 'Manatee' had more leaf damage (12.1\%) than '70096' but significantly less damage than 'Okeechobee' (19.8\%) and 'Terrapin' (19.1\%). BCB resistance in '70096' was confirmed in laboratory tests. BCB leaf damage in the three iceberg cultivars was similar ranged from $16.9 \%$ ('Raleigh') to $17.5 \%$ ('Gator') (Table 1). Mines tunneled by SL larvae in the romaine and iceberg cultivars were similar.

Aphids' natural infestation caused significant differences in damages observed in the romaine and iceberg cultivars. 'Okeechobee' was the most susceptible romaine cultivar (3.7 rating), with the presence of two or more dense colonies on most plants, whereas there were no dense colonies observed on 'Manatee', which had the lowest number of aphids (1.2) (Table 1). For iceberg cultivars, more aphids were observed on 'Raleigh', but no dense colonies were seen on any of the iceberg cultivars, suggesting that iceberg cultivars are less susceptible than romaine cultivars to potato aphids.

The lettuce planted on 7 October 2010 with insect control matured in early December. Yield data collected on 8 December is presented in Table 2. The romaine cultivars 'Manatee, 'Terrapin', and 'Okeechobee' hadhad similar yield that was significantly higher than breeding line '70096'. 'Gator' was superior in yield to the other two iceberg cultivars.

Lettuce planted on 22 October 2010 and without insect control matured in late January 2011. Yield in the three iceberg cultivars was affected under natural infestation, 
while the yield in the romaine cultivars was not significantly affected (Table 2). 'Gator' and '8074' had significantly heavier heads than 'Raleigh'.

Lettuce yield was reduced when insect infestations occurred, with a reduction by $14 \%$ in the romaine cultivar 'Manatee' and all three iceberg cultivars. 'Terrapin' and 'Okeechobee' had 3\% and 6\% lower yields, respectively, when grown under natural infestation. Interestingly, '70096' yield was $8 \%$ higher under natural infestation.

\section{Implications}

$\mathrm{BCB}, \mathrm{SL}$, or aphid damage was observed on all cultivars. The lowest was $3.7 \%$ leaf damage for cultivar ' 70096 ' in the $\mathrm{BCB}$ test (Table 1), suggesting that although this cultivar had the least BCB leaf damage, it is still susceptible to this pest.

Cultivars and breeding lines varied in their responses to infestations of these three insect pests. This data suggests that '70096' is resistant to BCB and 'Manatee' has some resistance to aphids because of the low numbers of aphids found on this cultivar (Table 1). The three iceberg cultivars showed different responses only to aphid infestation, 'Raleigh' had the most aphids counted (Table 1). Although, tested in separate experiments, all romaine cultivars but 'Manatee' had dense colonies of aphids, while there were no dense colonies on the iceberg cultivars, indicating that iceberg cultivars overall were less susceptible to aphids than romaine cultivars.

The yield of cultivars and breeding lines was affected by insect damage. Four of seven cultivars had much lower yield in the experiments without pesticide than in those with pesticide controlled (Table 2). The remaining three cultivars ('Okeechobee', 'Terrapin', and '70096') yielded similarly when treated or not with pesticides.

$\mathrm{BCB}$ is a midseason pest on lettuce in southern Florida. Growers usually apply pesticides to the crop twice to control the insect. Since aphids and SL are present from the middle through the end of the season, prophylactic aphid control is critical to the lettuce industry. Although pesticide application in the lettuce crop may be needed because the market requires that lettuce heads and hearts be free of insect contamination, the number of pesticide applications could be reduced if resistant cultivars to these pests are improved.

\section{References}

Drees, B. M, and J. Jackman. 1999. Field Guide to Texas

Insects. Houston, TX: Gulf.

Guzman, V. L. 1986. Short Guzmaine, Tall Guzmaine and Floriglade: Three Cos Lettuce Cultivars Resistant to Lettuce Mosaic Virus. S-326. Gainesville: University of Florida Institute of Food and Agricultural Sciences.

Guzman, V. L., and T. A. Zitter. 1983. Floricos 83: A Cos Lettuce Cultivar Resistant to Two Viruses, for Florida Organic Soils. S-305. Gainesville: University of Florida Institute of Food and Agricultural Sciences.

Huang, J., G. S. Nuessly, H. J. McAuslane, and F. Slansky. 2002. "Resistance to Adult Banded Cucumber Beetle (Coleoptera: Chrysomelidae) in Romaine Lettuce." J. Econ. Entomol.95 (4): 849-855. https://doi. org/10.1603/0022-0493-95.4.849

Liu, Y. B., and J. D. McCreight. 2006. "Responses of Nasonovia ribisnigri(Homoptera: Aphididae) to Susceptible and Resistant Lettuce." J. Econ. Entomol.99 (3): 972-978. https:// doi.org/10.1093/jee/99.3.972

McCreight, J. D. 2008. "Potential Sources of Genetic Resistance in Lettuce to the Lettuce Aphid, Nasonovia ribisnigri(Mosely) (Homoptera: Aphididae)." HortScience43 (5): 1355-1358. https://doi.org/10.21273/ HORTSCI.43.5.1355

Nuessly, G., and R. T. Nagata. 1993. "Evaluation of Damage by Serpentine Leafminer and Banded Cucumber Beetle to Cos Lettuce." Everglades Res. Edu. Ctr. Res. Rpt.2: 76-77.

Nuessly, G., and R. T. Nagata. 1994. "Differential Probing Response of Serpentine Leafminer, Liriomyza trifolii(Burgess), on Cos Lettuce." J. Entomol. Sci.29 (3): 330-338. https://doi.org/10.18474/0749-8004-29.3.330

Nuessly, G., and S. E. Webb. 2010. Insect Management for Leafy Vegetables. ENY-475. Gainesville: University of Florida Institute of Food and Agricultural Sciences. https:// edis.ifas.ufl.edu/ig161

Saba, F. 1970. "Host Plant Spectrum and Temperature Limitations of Diabrotica balteata." Can. Entomol.102 (4): 684-691. https://doi.org/10.4039/Ent102684-6 
Sethi, A., H. J. McAuslane, H. T. Alborn, R. T. Nagata, and G. S. Nuessly. 2008. "Romaine Lettuce Latex Deters Feeding of Banded Cucumber Beetle: A Vehicle for Deployment of Biochemical Defenses." Entomologia Experimentalis et Applicata128 (3): 410-420. https://doi. org/10.1111/j.1570-7458.2008.00732.x

Sethi, A., H. J. McAuslane, R. T. Nagata, and G. S. Nuessly. 2006. "Host Plant Resistance in Romaine Lettuce Affects Feeding Behavior and Biology of Trichoplusia niand Spodoptera exigua(Lepidoptera: Noctuidae)." J. Econ. Entomol.99 (6): 2156 -2163. https://doi.org/10.1093/ jee/99.6.2156

Smith, C. M. 1989. Plant Resistance to Insects: A Fundamental Approach. New York: Wiley. 
Table 1. Mean scores of banded cucumber beetle (BCB) feeding, serpentine leafminer (SL) tunneling, and aphids among lettuce cultivars in separate field experiments at Belle Glade, FL.

\begin{tabular}{|c|c|c|c|c|}
\hline Cultivar & Type & $\begin{array}{l}\text { BCB }^{1} \\
(\%)\end{array}$ & \begin{tabular}{|l|} 
SL \\
(\%)
\end{tabular} & Aphids Rating \\
\hline Okeechobee & Romaine & $19.8 a^{2}$ & 8.5 & $3.7 a$ \\
\hline Terrapin & Romaine & $19.1 \mathrm{a}$ & 9.4 & $3.1 \mathrm{~b}$ \\
\hline 70096 & Romaine & $3.7 c$ & 9.2 & $2.8 \mathrm{c}$ \\
\hline Manatee & Romaine & $12.1 \mathrm{~b}$ & 8.7 & $1.2 \mathrm{~d}$ \\
\hline Gator & Iceberg & 17.5 & 9.2 & $0.9 \mathrm{~b}$ \\
\hline 8074 & Iceberg & 17.3 & 10.0 & $1.0 \mathrm{~b}$ \\
\hline Raleigh & Iceberg & 16.9 & 11.5 & 1.8a \\
\hline \multicolumn{5}{|c|}{$\begin{array}{l}{ }^{1} \text { Percentage damage was used for } \mathrm{BCB} \text { and } \mathrm{SL} \text {, while a } 0-4 \text { scale rating method was employed for aphids as follows: } 0=\text { no aphids on the plant; } \\
1==10 \text { aphids on the plant; } 2=>10 \text { aphids but aphids scattered on the plant; } 3=1 \text { dense colony on } 1 \text { leaf of the plant; } 4=\text { dense colonies on } 2 \text { or } \\
\text { more leaves of the plant. } \\
\text { 'For each type, means in the column followed by the same letter are not significantly different }(\mathrm{a}=0.05) \text { using a least significant difference test } \\
\text { (SAS Institute, Cary, NC). }\end{array}$} \\
\hline
\end{tabular}

Table 2. Yields of lettuce cultivars planted with insect control on 7 October 2010 and harvested on 8 December 2010, and planted without insect control on 22 October 2010 and harvested on JanuaryJanuary 2011 at Belle Glade, FL.

\begin{tabular}{|c|c|c|c|c|c|c|}
\hline \multirow[b]{2}{*}{ Cultivar } & \multirow[b]{2}{*}{ Type } & \multicolumn{2}{|c|}{ Yield (lb/./head) } & \multicolumn{2}{|l|}{ Yield (kg/head) } & \\
\hline & & Insect control & $\begin{array}{l}\text { No insect } \\
\text { control }\end{array}$ & Insect control & $\begin{array}{l}\text { No insect } \\
\text { control }\end{array}$ & $\begin{array}{l}\text { No insect control/Insect control } \\
(\%)\end{array}$ \\
\hline Okeechobee & Romaine & $2.01 \mathrm{a}^{1}$ & $1.91 \mathrm{a}$ & $0.93 a^{1}$ & $0.87 \mathrm{a}$ & 94 \\
\hline Terrapin & Romaine & $2.05 \mathrm{a}$ & $1.98 \mathrm{a}$ & $0.93 a$ & $0.90 \mathrm{a}$ & 97 \\
\hline 70096 & Romaine & $1.58 \mathrm{~b}$ & $1.72 \mathrm{a}$ & $0.72 \mathrm{~b}$ & $0.78 \mathrm{a}$ & 108 \\
\hline Manatee & Romaine & $2.20 \mathrm{a}$ & $1.65 \mathrm{a}$ & $1.00 \mathrm{a}$ & $0.75 a$ & 75 \\
\hline Gator & Iceberg & $1.83 \mathrm{a}$ & $1.41 \mathrm{a}$ & $0.83 a$ & $0.64 a$ & 77 \\
\hline 8074 & Iceberg & $1.45 \mathrm{~b}$ & $1.25 \mathrm{a}$ & $0.66 \mathrm{~b}$ & $0.57 \mathrm{a}$ & 86 \\
\hline Raleigh & Iceberg & $1.47 \mathrm{~b}$ & $0.92 b$ & $0.67 \mathrm{~b}$ & $0.42 \mathrm{~b}$ & 63 \\
\hline
\end{tabular}

